\title{
Stakeholder-Formed Organizations and Crisis Communication: Analyzing Discourse of Renewal with a Non-Offending Organization
}

\author{
Jordan Morehouse ${ }^{1}$ (1)
}

1. Assistant Professor of Strategic Communication, Clemson University, 408 Strode Tower, Clemson, SC, USA

\begin{abstract}
Scholars have examined the ways organizations practice post-crisis communication strategies, including deny, diminish, and rebuild. The current study explores the extent to which a stakeholder-formed organization utilizes post-crisis discourse of renewal to rebuild, recover, and renew the Catholic Church after allegations of sexual abuse of minors publicly surfaced in the United States. Open-ended semi-structured interviews with founders and executive committee members of Leadership Roundtable revealed stakeholders practiced discourse of renewal to help the Catholic Church, an offending organization, recover from a crisis. This study also assessed the extent to which God and religion motivated stakeholders' responses. Results suggest religion is a critical motivating factor in stakeholders' responses to a crisis.
\end{abstract}

No organization is exempt from experiencing a crisis. Accidental, intentional, and victim crises occur regardless of the organization's purpose, size, or preparedness (Coombs, 2007). Religious organizations and institutions are no exception (Barth, 2010). The Catholic Church has experienced a number of crises from sexual abuse (Barth, 2010), abuse of power (Keenan, 2012) to mismanagement of funds (Kirchgaessner, 2015). One crisis in particular, the revelation of sexual abuse of minors at the hands of the Church's clergy, has received exceptional attention from

CONTACT Jordan Morehouse (D) • Email: jlmoreh@clemson.edu • Clemson University, 408 Strode Tower, Clemson, SC 29634, USA 
journalists and scholars alike (Barth, 2010; Boys, 2009; Dokecki, 2004; Donnelly \& Inglis, 2010; Maier, 2005). Despite the decades in which this crisis has unfolded and continually occurred, research on crises within religious organizations is limited.

\section{The Crisis Communication Problem}

There are three crisis communication problems regarding research on the Catholic sexual abuse crisis and crisis communication within religious organizations overall. First, crisis communication scholars have mainly focused on the Catholic Church's response to the crisis, as opposed to stakeholders' responses (e.g., parishioners) (Barth, 2010; Maier, 2005). Several scholars have taken steps to shift the focus of public relations practice and theorizing from organizations to stakeholders (cf. Yang \& Taylor, 2014), but this has not yet reached research on religious crises or religious institutions and organizations (Boys, 2009). Second, crisis communication scholars have not considered the extent to which religion or belief in a deity, like God, can impact the crisis response and post-crisis reputation (Spaulding, 2018; Tilson \& Venkateswaran, 2006). Ignoring or minimizing the influence of God or religion from research on religious organizations results in an incomplete understanding of the phenomenon at hand. Lastly, there is a primary limitation that unnecessarily restricts the ways in which discourse of renewal, the post-crisis communication framework utilized in the current study, can be studied or applied during a crisis.

Many scholars study discourse of renewal as a post-crisis communication activity that only the offending organization can utilize when communicating with their stakeholders (Seeger \& Ulmer, 2002; Ulmer \& Sellnow, 2002; Xu, 2018). Such approach to studying discourse of renewal excludes stakeholders and stakeholder-formed organizations. In this context, stakeholder-formed organizations are non-profit organizations, activist groups, or other groups that are created by stakeholders of the offending organization as a response to a crisis (Agné et al., 2015; Boys, 2009). Excluding stakeholders and their post-crisis communication efforts constrains the field's understanding of who can 
practice public relations, how non-offending organizations or groups can practice public relations, and what public relations is. Furthermore, a crisis is defined as a negative event that "threatens important expectancies of stakeholders and can impact an organization's performance" (Coombs, 2009, p. 99). Thus, understanding stakeholders' threatened expectations, stakeholders' responses to the negative event, and stakeholders' responses to threatened beliefs is pertinent in order to understand the magnitude of the crisis and harm caused to the organization's reputation and stakeholders themselves. Thus, the broad purpose of this research is to explore if, how, and why stakeholders can adopt a post-crisis discourse of renewal following the sexual abuse crisis from the Catholic Church.

\section{Purpose of Research}

The purpose of this research is to further public relations and crisis communication theory development in three ways. First, this study will analyze stakeholders' perspectives of the crisis, and assesses the actions specific stakeholders took following a global revelation about the crisis. The specific stakeholders are founders and past and present executive board members of Leadership Roundtable, a non-profit organization. The current study categorizes Leadership Roundtable as a stakeholder-formed organization because the organization was formed after the Boston Globe article was published and leadership within the organization strategically consists of stakeholders to the Catholic Church (e.g., parishioners, donors, volunteers). Second, this study considers the extent to which an abstract entity (e.g., God) or unifying issue (e.g., religion) can influence stakeholders' response to and perception of the crisis. Third, this study will also expand on how discourse of renewal is applied and studied. Traditionally, discourse of renewal is examined by analyzing the offending organization's adoption of rhetoric that focuses on ownership of the crisis, a commitment to rebuild, and the crisis as an opportunity for renewal (Seeger \& Ulmer, 2002). This research will view the potential for stakeholders to utilize discourse of renewal. 


\section{Crisis: Abuse of Minors within the Catholic Church}

The abuse of young men and women at the hands of Catholic leaders is a global problem. The issue first came to light in the media in the 1980s, despite the abuse itself taking place as early as the 1950 s (Catholic Church Child Sexual Abuse Scandal, 2019). Through the years, news media reported on isolated occurrences throughout Central and South America, Europe, and Australia. However, media coverage of the crisis escalated to a global platform in 2002 when the Boston Globe newspaper published an article detailing years of widespread abuse, lack of punishment, and lack of accountability within the Catholic Church (Robinson, 2002). As a result, the Catholic Church began responding to claims and acting by creating Church-commissioned reports and committees (Catholic Church Child Sexual Abuse Scandal, 2019).

The outrage that followed the Boston Globe's revelations focused on the abuse itself, on the lack of punishment of pedophilic Catholic leaders on behalf of the Church, and on communication following the revelations (Barth, 2010). For instance, the Church was criticized for turning inward and relying on bureaucracy when they should have paired a reliance on bureaucracy with "personal involvement," empathy, and rational personal judgment (Barth, 2010, p. 785). This reliance on bureaucracy meant that pedophilic Catholic leaders were allowed to lead parishioners again after receiving "treatment" for pedophilia, something scientists now know is not "curable" (Barth, 2010, p. 785). Despite the creation of charters, Church-commissioned reports, and the introduction of multiple new Church-led programs and practices, scholars and, the public agree that the Church has consistently mishandled and botched the post-crisis communication (Barth, 2010).

Contrary to the approach other crisis communication research has taken, this study does not focus on the offending organization's crisis response. Instead, this study examines stakeholders' perspectives and responses to the crisis. A stakeholder-centered approach is critical to theory development because public relations does not only function to benefit organizations. 


\section{Discourse of Renewal}

Discourse of renewal is a post-crisis communication framework in which offending organizations engage in a "discourse of renewal ... [which] focuses on the future, how previous limitations can be overcome and what new opportunities can be explored" (Seeger \& Ulmer, 2002, p. 137). In other words, the post-crisis dialogue centers on renewal, change, reassurance, and optimism regarding the future (Fuller et al., 2019). Research suggests that the focus on "renewal" and the future is driven by the personal values and ethics of the organization's leaders (Fuller et al., 2019; Seeger \& Ulmer, 2002). Discourse of renewal serves as a direct contrast to apologia, a defense-based approach where organizations either deny the crisis, claim they are not responsible for the crisis, attempt to reduce the severity of the crisis, offer compensation, offer corrective action, or display mortification (Manzie, 2018; Seeger \& Ulmer, 2002). To practice post-crisis discourse of renewal, organizations "connect with [their] core values 'to reconnect the past to the present, to rediscover the old in the new"' (Hurst, 1995, p. 3; Seeger \& Ulmer, 2002, p. 127). This involves reiterating a commitment to stakeholders, to rebuild, and to organizational renewal (Thompson et al., 2017).

\section{Themes and Strategies within Discourse of Renewal}

The first theme discourse of renewal research centers on is a commitment to stakeholders. Scholars explain that the commitment to stakeholders focuses on a commitment to transparency with stakeholders, of financially or physically caring for stakeholders, developing relationships with them, and their general well-being (Seeger \& Ulmer, 2002). In practice, a commitment to stakeholders can look different depending on the crisis and organization. For instance, Ulmer and Sellnow (2002) detailed that after the 9/11 terrorist attacks on the World Trade Center, New York City police officers and firefighters communicated a commitment to stakeholders by continually reminding stakeholders that they will give their lives to save others. On the other hand, Seeger and Ulmer (2002) explained that two other organizations at the center of a different crisis communicated a commitment to stakeholders 
by promising to pay employee salaries while the organization embarked on a 2-year construction process.

The second theme highlighted in discourse of renewal research is a commitment to rebuild. A commitment to rebuild is typically associated with rebuilding a physical structure. For example, the offending organization communicated a commitment to rebuilding facilities that burned down in Seeger and Ulmer's (2002) study. To build upon Seeger and Ulmer's conceptualization of discourse of renewal, the current study posits that a commitment to rebuild can be communicated for non-physical structures like programs, laws, safety features, and trust. For instance, an organization can communicate a commitment to rebuilding trust in an organization, rebuilding lives that were destroyed by sexual abuse, or rebuilding policies that failed to protect vulnerable stakeholders.

The last theme researchers associate with discourse of renewal is a commitment to renewal. A commitment to renewal emphasizes dedication and devotion in renewing the organization's productivity, design, programs, purpose, and values. For instance, in Seeger and Ulmer's (2002) research, the offending organization communicated a commitment to renewal by focusing on an improved facility design and by emphasizing the placement of stakeholders and their immediate community at the core of their organization. This was mirrored in Ulmer and Sellnow's (2002) results, which suggest that American political leaders and businesses communicated a commitment to renewal by reinforcing core values such as "patriotism and independence ... and determination" after the 9/11 terrorist attacks (p. 364).

In addition to the three themes, scholars posit that organizations employ five communication strategies when utilizing discourse of renewal (Ulmer, Seeger, \& Sellnow, 2007; Xu, 2018). First, post-crisis communication must consist of a natural and immediate response, as opposed to a calculated response aimed at shifting blame or protecting the organization from further reputational damage (Ulmer, Seeger, \& Sellnow, 2007). The second strategy includes prospective communication, and the third strategy focuses on optimistic communication regarding future opportunities as a result of the crisis (Ulmer, Seeger, \& Sellnow, 2007). The final two strategies within this framework include (4) ethical 
communication (5) from a leader within the organization (Seeger \& Griffin Padgett, 2010; Xu, 2018).

\section{Limitations in the Current Conceptualization}

There are important limitations in the current application and study of discourse of renewal. Namely, scholars have excluded the ways stakeholders can practice discourse of renewal and instead focus on the application of this post-crisis communication strategy from the offending organization. Second, there is limited research on what can be rebuilt for the second theme in discourse of renewal. Researchers have focused on rebuilding physical structures (Seeger \& Ulmer, 2002), however the current study posits that this theme can be applied to non-physical structures, like an organization's image (Thompson et al., 2017), stakeholder confidence in the organization (Ulmer \& Sellnow, 2002), trust, policies, training programs, and more. Lastly, scholars have restricted the utilization of one strategy in post-crisis discourse of renewal. The last strategy focuses on communication from a leader within the offending organization $(\mathrm{Xu}, 2018)$. The current study posits that the communication can come from a leader outside of the offending organization, including a victim of the crisis, a leader of a stakeholder-formed organization, or a leader within a related industry. The current study aims to build upon previous research and further scholarship on discourse of renewal by addressing each of these limitations.

\section{Leadership Roundtable}

Before discussing previous research on the Catholic sexual abuse crisis specifically, it is imperative to identify and describe the stakeholder-formed organization that is central to this study. Leadership Roundtable is a 501(c)(3) non-profit organization that educates and promotes "best practices and accountability in the management, finances, communication, and human resource development of the Catholic Church" (leadershiproundtable. org, n.d.). The organization was officially formed in 2005 after a 3-day gathering in 2004 that joined industry leaders working in for-profit and non-profit organizations within the U.S. More on 
the inspiration behind the gathering and creation of Leadership Roundtable is presented in the results section.

To clarify, Leadership Roundtable is a separate and independent organization from the Catholic Church. While a small portion of current executive members are religious leaders within the Catholic Church, there are a number of distinguishing features unique to Leadership Roundtable's bylaws and governance that preserves its independence from the Catholic Church. ${ }^{1}$ Furthermore, according to interviews with the founder of Leadership Roundtable, the Catholic Church was originally not receptive to Leadership Roundtable's services or resources in the early years of Leadership Roundtable's existence.

Currently, Leadership Roundtable consists of leaders in business, finance, academia, philanthropy, and non-profit organizations. Leaders within Leadership Roundtable (e.g., executive committee members) are devout and life-long Catholics who have volunteered or served in their respective parishes. At its core, Leadership Roundtable offers consultancy services to archdioceses, dioceses, parishes, and other Catholic communities and organizations within the U.S. regarding best practices in human resources, finances and other managerial operations. Therefore, individuals

1. According to Kerry Alys Robinson, a participant in this study, "the Catholic Church, in the U.S. alone, is comprised of 197 dioceses, 17,000 parishes, and countless schools, hospitals, and charities and each of these has a separate governance structure. Having said that, many Catholic nonprofits have a bishop on their board or have sought to be recognized as an official Catholic entity in order to be listed in the Official Catholic Directory which can help them to receive grant funding from Catholic foundations, for example. Leadership Roundtable was set up intentionally as an independent entity, with no bishop on its board, with no governance structure that would require it to seek permission or approval from the bishops in the U.S. or in Rome and with no listing in the Official Catholic Directory. [Leadership Roundtable is] independent entirely from the United States Conference of Catholic Bishops which is why we are able to present ourselves as an independent, nimble, effective partner to the bishops. One of the ways we have earned [the Church's] trust and confidence even while being outside of their control is by not wading into doctrinal matters but focusing solely on what we do best: problem solve, introduce best practices, strengthen management, finance, communications and human resources, to allow for the Church's mission to flourish unencumbered. Having a nun or a priest or even a layperson on our board who happens to work for another Catholic organization in no way detracts from our independence. And yet it strengthens our mission. It should also be noted that board members are not paid for their service on our board." 
who utilize Leadership Roundtable's services and resources are formally tied to the Catholic Church or other Catholic organizations.

The current study focuses on Leadership Roundtable specifically because of their unique organizational purpose. Other stakeholder-formed organizations like Don't Be Afraid Foundation, Healing Voices, Voice of the Faithful, and Survivors Network of those Abused by Priests primarily aim to help survivors of sexual abuse. Leadership Roundtable strategically does not provide any resources, training, or aid for survivors of sexual abuse. Instead, Leadership Roundtable's goal is to assist the Catholic Church and Catholic organizations in implementing best practices in human resources, accounting, management, and other business-related functions. Founders posit that the crisis occurred as a result of immoral and unethical behavior, and a breakdown in industry best practices. Leadership Roundtable presents a unique case, one that deserves further scrutiny, to which can inform public relations theory and our collective understanding post-crisis communication and crises within religious organizations.

\section{Post-Crisis Communication and the Catholic Sexual Abuse Crisis}

Public relations scholars who study religious organizations, and specifically crises within the Catholic Church, have approached the area in many ways. However, scholars have reached a similar conclusion, namely that the Catholic Church mismanaged the post-crisis communication, which resulted in additional unnecessary pain and suffering. For instance, Maier (2005) discussed their personal experience working for the Catholic Church and applied theory of publics to their research in order to organize a list of conclusions regarding the Church's response (cf. p. 223). Ultimately, Maier (2005) argued for the importance of engaging in dialogue with publics before, during, and after a crisis, and concluded that an organization can recover from a crisis by establishing relationships characterized by openness, attentiveness, and responsiveness. These conclusions regarding relationship development in post-crisis plans are pertinent to our collective understanding 
of crisis recovery. Barth (2010) proposed similar steps as Maier (2005), like building community and relationships, in their conceptual paper. However, Barth (2010) focused on the Church's response and examined the sexual abuse crisis through the lens of crisis management theory. Barth (2010) outlined several reasons as to why the Church failed in their crisis communication efforts and noted that the Church "lost sight of their primary mission: the spiritual care and general welfare of the members of the Church" (p. 784). Importantly, Barth acknowledged the impact of religion and God in the crisis and crisis response strategy, which is an important step toward a holistic approach.

On the other hand, Boys (2009) examined post-crisis communication from the Church and from specific stakeholders. To do this, Boys (2009) analyzed messages from the Church and two stakeholder-formed organizations: Voices of the Faithful and Survivors Network of those Abused by Priests. Results from their examination suggest that each organization "employed different types of crisis communication in hopes of meeting different crisis outcomes" (p. 305). For instance, Boys (2009) described the ways in which the Survivors Network organization critically approached crisis communication with the ultimate goal of ending sexual abuse by Catholic clergy, whereas the Voices of the Faithful organization utilized a "responsive orientation to seek legitimacy and influence" (p. 305).

While public relations research on the Catholic Church sexual abuse crisis is increasing, current research has notable limitations. For instance, Maier (2005) did not consider the unique context in which relationships occur between stakeholders and a religious institution, nor the religion that binds these parties together. Overlooking the influence of religion and God in a religious crisis constrains our understanding of crisis recovery. For example, does the stakeholder's relationship with God remain stable, improve, or suffer when the Catholic Church's reputation is damaged by a crisis? On the other hand, Barth (2010) only examined the Church's post-crisis communication while overlooking stakeholder's perspectives of and responses to the crisis. This approach limits our understanding of the threatened expectancies of stakeholders (Coombs, 2009). Lastly, Boys (2009) analyzed press releases from 
stakeholder-formed organizations as opposed to interviewing or surveying the stakeholders. While Boys's approach is important and necessary, it also means that to date, there is little research conducted analyzing stakeholders' personal accounts of the crisis and aftermath.

The current study will address these limitations in order to further our understanding of stakeholders' responses to religious crises, discourse of renewal, and the impact of God and religion. Understanding and exploring stakeholder perspectives, approaches, reasons, and beliefs regarding the crisis communication, crisis management, and unifying entity is pertinent in order to take a holistic approach to crisis communication and public relations theorizing on religious organizations. To do this, the author entered the field with two broad questions in mind; however, a third question quickly emerged during data collection:

\begin{abstract}
RQ1: What post-crisis communication strategy did Leadership Roundtable utilize, and what drove that approach?

RQ2: To what extent can a stakeholder-formed organization practice discourse of renewal for the offending organization?

RQ3: To what extent does an abstract entity, like God, or unifying issue, like religion, impact the selection of a post-crisis communication strategy?
\end{abstract}

\title{
Method
}

To explore if, how, and why religious stakeholders employ discourse of renewal, as well as the role of religion and God in a post-crisis communication approach, the author interviewed 11 past and current leaders and members within Leadership Roundtable. Participants include current and past chief executive officers of Leadership Roundtable, the original organizer of the 2004 three-day gathering, multiple past and present executive committee members, the founding executive director, the current global ambassador of Leadership Roundtable, as well as participants who utilize Leadership Roundtable's resources. Each participant is a devout Catholic with multiple decades of belief and 
experience with the religion. As a result, each participant has a unique history with the Catholic Church. For example, Kerry Alys Robinson (founding executive director and current global ambassador of Leadership Roundtable) held the position of Director of Development at Saint Thomas More Catholic Chapel \& Center at Yale University from 1997 to 2006, while other participants like James Dubik, PhD, retired Lieutenant General in the U.S. Army (executive board member), is a parishioner who has not participated in any formal paid work for or with the Catholic Church. ${ }^{2}$

While the number of participants may appear small, this approach mirrors previous research on discourse of renewal (Seeger \& Ulmer, 2002; Thompson et al., 2017; Wastell et al., 2007) and was necessary given the study's purpose and the type of insider historical information that is needed in order to answer the questions posed (Merriam, 2009). For example, Seeger and Ulmer (2002) interviewed two CEO's along with an undisclosed number of "staff and ... members of the community" (p. 131). Interviews were conducted in person during the Engaging, Equipping, and Energizing Catholic Leaders for the Joy of the Gospel conference and over the phone. Data collection lasted from June 2017 to November 2017. Interviews lasted on average 41 minutes, with the longest lasting 56 minutes and the shortest lasting 28 minutes. Each interview was audio recorded and after transcribing the interviews, the transcripts exceeded 110 pages.

To analyze the data, the researcher utilized the Straussian grounded theory approach to qualitative data analysis (HowardPayne, 2016). The Straussian approach includes systematic procedures like open, axial, and selective coding (Strauss \& Corbin, 1998). Importantly, within the Straussian grounded theory approach, researchers browse existing research before entering the field, and enter the field with a question in mind (Howard-Payne, 2016; Strauss \& Corbin, 1998). Therefore, the researcher entered the field with general knowledge of various crisis communication strategies and the general question of, "What post-crisis

2. Dubik's volunteer service to the Catholic Church includes serving as an altar server in grade and high school, lector in college and as an adult, a guitarist in choirs, and taught children the Confraternity of Christian Doctrine for 2 years. 
communication strategy did Leadership Roundtable utilize, and what drove that approach?"

Because of the researcher's general knowledge of various crisis communication strategies, it became apparent during data collection that Leadership Roundtable utilized discourse of renewal. Therefore, after identifying the post-crisis communication strategy Leadership Roundtable utilized and factors that drove their approach during data collection, it became important to also answer the question of, "To what extent can a stakeholder-formed organization practice discourse of renewal for the offending organization?" Additionally, to examine the ways in which religion and God impacts stakeholders' post-crisis actions, the final question emerged as "To what extent does an abstract entity, like God, or unifying issue, like religion, impact the selection of a post-crisis communication strategy?" The results section will address each of the three broad questions posed.

To answer the last two questions, which focus on stakeholderformed organizations practicing discourse of renewal and the influence of God and religion, the researcher continued to utilize the Straussian grounded theory approach to data analysis by employing open, axial, and selective coding. During this process, over 50 open codes were categorized into axial codes, which were then organized into selective codes that informed the results of this research (see Table 1). Importantly, theory was incorporated into the data analysis process, which is atypical in Glaser's grounded theory approach to data analysis (Glaser \& Strauss, 1967), but acceptable according to the Straussian grounded theory approach to data analysis (Howard-Payne, 2016).

TABLE 1 Open Codes

\begin{tabular}{|l|l|}
\hline Connections by relationships & LR testimonials \\
\hline Connections by enlightenment* & LR future goals \\
\hline Connections by proximity & LR goals achieved* \\
\hline Connections work-local & "New focus"* \\
\hline Connections work-national & $\begin{array}{l}\text { "What could we bring to the } \\
\text { Church?" }\end{array}$ \\
\hline
\end{tabular}




\begin{tabular}{|c|c|}
\hline Connections personal & Interactive media \\
\hline Connections church-local & Interactive conversations \\
\hline Connections_-informal advising & Church involving laity \\
\hline Forming relationships in community & Church excluding laity \\
\hline Forming relationships across U.S. & Church response to LR-positive \\
\hline Forming international relationships & Church response to LR-negative \\
\hline $\begin{array}{l}\text { Inspiration-religious-God/Holy } \\
\text { Spirit }\end{array}$ & Emotions_before crisis (BG article) \\
\hline Inspiration-religious-personal & Emotions-after crisis (BG article) \\
\hline Inspiration-religious-Bible* & Church critique \\
\hline Inspiration-religious-network & Questioning activism* \\
\hline Inspiration-industry & $\begin{array}{l}\text { Personality description-non- } \\
\text { religious }\end{array}$ \\
\hline Inspiration-feminist* & Personal history \\
\hline Internal processes-non-profit orgs & Response to crisis-personal \\
\hline Internal processes-for-profit orgs & Interpretation of Church response \\
\hline Internal processes-army* & Actions-before crisis (BG article) \\
\hline Professional history-story & Actions-after crisis (BG article) \\
\hline Professional history—background & Religious history-story \\
\hline Management experience & Religious history—background \\
\hline Active industry leader & Response to crisis-religious \\
\hline Laity in positions of authority & $\begin{array}{l}\text { "Responding when asked"—God/ } \\
\text { Holy Spirit }\end{array}$ \\
\hline Laity leadership & Personality description-religious* \\
\hline $\begin{array}{l}\text { "Responding when asked"- } \\
\text { professional }\end{array}$ & $\begin{array}{l}\text { "Humans are flawed"/"Humans make } \\
\text { errors" }\end{array}$ \\
\hline Response to crisis-professional & Bible-quote, verse, story* \\
\hline LR services & Feminism* \\
\hline LR success & $\begin{array}{l}\text { "Women in Church"-personal } \\
\text { stories* }\end{array}$ \\
\hline LR history & Internal processes-Catholic church \\
\hline LR origin & \\
\hline \multicolumn{2}{|c|}{$\begin{array}{l}\text { Note. An asterisk }\left(^{*}\right) \text { indicates that } 1-2 \text { participants aligned with this code. Codes } \\
\text { without an asterisk indicate a majority of participants aligned with the code. }\end{array}$} \\
\hline
\end{tabular}




\section{Results}

Leadership Roundtable employed, and continues to employ, post-crisis discourse of renewal for crises regarding the Catholic Church. Through interviews with founders and executive committee members, it became evident early on during the data collection and analysis process that Leadership Roundtable practiced discourse of renewal. Leadership Roundtable did this by communicating a commitment to three different stakeholder groups, a commitment to rebuilding trust and ethical operations within Catholic dioceses and parishes, a commitment to renewal regarding the Catholic Church's values, purpose, and ethics, and by utilizing all discourse of renewal strategies (Ulmer, Seeger, \& Sellnow, 2007; Xu, 2018).

\section{Commitment to Stakeholders}

Like many organizations included in studies on discourse of renewal, Leadership Roundtable has various stakeholders they need to communicate with after a crisis occurred (Seeger \& Ulmer, 2002; Ulmer, Seeger, \& Sellnow, 2007; Ulmer \& Sellnow, 2002). However, unlike other organizations, Leadership Roundtable was not the offending organization. Indeed, Leadership Roundtable was formulated after the crisis occurred, yet Leadership Roundtable communicated a commitment to the following stakeholder groups: the Catholic Church (the international institution), Catholic leaders in the U.S., and believers of the Catholic faith.

\section{Commitment to the Catholic Church (Institution)}

The interview data reveal that while participants are personally stakeholders to the Catholic Church (e.g., laity), Leadership Roundtable as an organization utilized discourse of renewal to communicate a commitment to the Catholic Church as a stakeholder of the Leadership Roundtable organization. Meaning, Leadership Roundtable aimed to help the Catholic Church as an institution recover from the crisis with strategic objectives, goals, and tactics. This commitment was communicated in multiple ways, but is most apparent in the first few years of Leadership 
Roundtable and in the current purpose and function of the organization.

During the first few years of Leadership Roundtable's existence, participants in the organization aimed to strategically support the Catholic Church through members' expertise in business and communication practices. Leadership Roundtable's Founding Executive Director and current global ambassador, Kerry Alys Robinson, described the purpose succinctly:

[Leadership Roundtable] came into existence because in examining how we could be part of the solution, how we could help affect healing and reconciliation in our faith family, the Church, we wanted to bring underutilized expertise, skills, perspective, and a way of serving the Church. We wanted to remind the Church that there's managerial excellence, experience, financial acumen, and cogent analysis that Catholic laity are willing to provide Church leaders for free to strengthen the Church.

In other words, Leadership Roundtable utilized an under-utilized resource: the professional experience and expertise of believers of the Catholic faith. Research participants, including Robinson and Geoff Boisi, Founding Chair of Leadership Roundtable and current Chairman and Chief Executive Officer of Roundtable Investments, explained that Leadership Roundtable was not created to directly help with the sexual abuse crisis. Data reveal that leaders expressed discomfort in providing advice and guidance on an issue that they were not trained in or experts in, like sexual abuse. Instead, Leadership Roundtable was created to assist in alleviating problems that led to the sexual abuse crisis, like poor hiring practices, unethical leadership, lack of transparency, and communication. Their hope was that excellent training from current industry professionals would decrease the potential and possibility of a similar crisis from occurring. For example, with better training and improved policies, pedophiliac individuals would be removed from positions of authority and distanced from vulnerable stakeholders, as opposed to maintaining their position of power and shuffled from parish to parish.

To communicate a commitment to the Catholic Church, founding members sought advice and guidance from devout Catholics who are leaders within their various industries. According to 
Boisi, the very first meeting of Leadership Roundtable consisted of 70 "lay folks ... who had expertise in the different functional areas including governance, management, human resource . . . financial resource development and accountability . . . and communications." During these initial meetings, attendees created a list of recommendations they or others wanted to provide to the Church. The list of recommendations focused on the ways in which industry leaders can assist or support the Church in alleviating current problems, preventing future ones, and training Church leaders to identify and resolve issues independently. Also included in the list of recommendations were methods and strategies to improve crisis communication. In the years that followed, as a result of increased trust between the Church and Leadership Roundtable, Leadership Roundtable went beyond communicating a commitment and ultimately worked with the Catholic Church to implement these recommendations and train Catholic leaders.

\section{Commitment to Catholic Leaders within Dioceses, Parishes, and Other Organizations}

To communicate their commitment to Catholic leaders within dioceses, parishes, and other Catholic organizations, Leadership Roundtable implemented a three-step plan. First, the stakeholderformed organization sought to understand the specific problems individual dioceses, parishes, and Catholic organizations faced in the U.S. Then, they identified any regional or national trends. Lastly, Leadership Roundtable created training programs, educational materials, and sample policies and gave these resources to Catholic leaders. The goal is for Catholic leaders to adopt and then implement these new programs, materials, and policies within their parishes and organizations.

Following many nationwide surveys and discussions with Catholic leaders and laity, Leadership Roundtable created programs, policies, and educational materials to help Catholic leaders govern, lead, and manage their parishes, dioceses, and organizations. For instance, Leadership Roundtable created a Catholic Standards for Excellence program, which is comprised of 55 "best church management practices" (leadershiproundtable.org, n.d.). To educate Catholic leaders on the program, Leadership 
Roundtable offers consultant training so that Catholic leaders can fully immerse themselves in the 55 recommended practices, and then assist in implementing the practices throughout their organizations and parishes.

Importantly, in addition to offering training on best practices in management, human resources, communication, finances, and more, Leadership Roundtable also partnered with other Catholicbased organizations (e.g., dioceses and seminaries) to compile a "Toolbox for Pastoral Management" for Catholic leaders. Within the toolbox, senior-level pastors and lay leaders provide advice and guidance on the business side of Church management (e.g., fundraising, leadership development, communication, human resources, finances) and also on the religious side of Church management (e.g., pastoral planning, volunteer management).

\section{Commitment to Believers of the Catholic Faith}

One of the fundamental stakeholder groups Leadership Roundtable communicated a commitment to are believers of the Catholic faith. Leaders of the organization explained that helping the Church recover and renew their programs, purpose, and values is simultaneously helping Catholic believers and laity. For instance, when the Church experiences mistrust or a damaging reputation as a result of a crisis, believers of the Catholic faith also suffer the consequences of the Church's crisis. To communicate their commitment to believers of the faith, the leaders within Leadership Roundtable considered lay people's perspectives, opinions, hurts, and struggles with the Church and Church leaders, and sought their feedback on new recommendations, programs, and responsibilities. Furthermore, the primary goal of Leadership Roundtable is to encourage the involvement of laity (i.e., nonordained Catholic believers) within diocesan, parish, and organizational operations.

\section{Commitment to Rebuild}

Interview data reveal Leadership Roundtable communicated a commitment to rebuilding trust, ethical operations, and improved operations within the Catholic Church. While no 
physical structures or facilities needed to be reconstructed (Seeger \& Ulmer, 2002), the broken trust, damaged reputation, poor management, and outdated policies needed to be rebuilt, reestablished, and taught to all levels of leaders in all Catholic organizations, including parishes and schools. Dubik describes the commitment to rebuild succinctly:

What we asked ourselves was, "How can we help the Church move from where it is, to where it ought to be?" That's how we developed [Leadership Roundtable's] mission, our vision, our guiding principles, and our strategy, knowing that we don't run the Church. We had a transformational mission for trying to transform an organization for which we were not responsible. When we described our mission that way, that helped inform us on how we had to proceed and what strategy we should develop.

Rebuilding trust and outdated policies were top priorities and the primary focus in the first several years of Leadership Roundtable, which was a particularly difficult task since the Church was not keen on accepting help from Leadership Roundtable in the first few years. Founding members acknowledged that rebuilding trust in the Church would be a decades-long effort. However, rebuilding and updating outdated policies was a practical solution that could be addressed, corrected, disseminated, and employed at a quicker pace. To rebuild outdated policies, Leadership Roundtable developed the Catholic Standards for Excellence. The Catholic Standards of Excellence allowed the organization to update policies that had failed and create new policies to secure safety, transparency, and ethical interactions, management, and leadership. Additionally, the organization rebuilt operations within the Church by offering consulting, road mapping tools, assessment tools, a "toolbox" of programs and procedures, and development programs for the next generation of Catholic leaders (leadershiproundtable.org, n.d.).

\section{Commitment to Renewal}

Interview data reveal Leadership Roundtable communicated a deeply-rooted commitment to renewal in Catholic faith, values, purpose, and ethics in business and communication. There are two key areas of renewal that Leadership Roundtable sought to 
restore. First, the sexual abuse crisis signaled distance from the Catholic faith and values. The Catholic Church is against sexual abuse, abuse of power, manipulation of minors, and pedophilia. However, the Church does believe in a system of repentance, forgiveness, and rehabilitation. Therefore, Leadership Roundtable specifically did not advise or provide programs regarding doctrinal issues, liturgy, or specifics on sexual abuse, because according to participants, these topics were not within their area of expertise. Instead, the founders combined their industry expertise and ethics with Catholic values to create a custom approach to renew management, communication, and operations within the Church, parishes, dioceses, and other Catholic organizations. Dubik expressed their contributions concisely:

We were here to help reform temporal management and leadership affairs. We were not going to comment on any matters of faith, any matters of doctrine, any matters of dogma. That's not our role. Our role is to help [the Church] think through how to be better stewards of the resources, people, facilities, and money that the ecclesiastic leaders have at their disposal.

Therefore, while the sexual abuse crisis signaled distance from Catholic faith and values, Leadership Roundtable utilized their industry expertise and experience to revitalize and renew the commitment to and communication of Catholic faith and values, while not advising on Catholic doctrine, religious practices, sexual abuse, or the like.

Leadership Roundtable communicated a commitment to renewing Catholic values by creating policies, programs, and training resources that expertly tie Catholic values with industry values. For instance, the Catholic Leadership 360 program combines Biblical leadership with industry leadership best practices. The result is a 3 -to-4-month training program that educates priests and lay ministers on "leadership development, performance improvement, and interpersonal communication" (leadershiproundtable.org, n.d.). Within this program, Catholic leaders are trained on Biblical leadership values, like integrity, humility, and servant leadership as well as industry leadership values, like resilience, adaptability, and accountability. 
The second area of renewal focused on the Church's poor management of the crisis and communication. The Church's poor handling of the crisis and poor communication after the crisis went public signaled distance from ethical and transparent communication. For instance, instead of firing pedophiliac leaders immediately upon news of their crimes, the Church demoted them, shuffled them around to different parishes or dioceses, or at worse, promoted them (Catholic Church Child Sexual Abuse Scandal, 2019; Green, 2019). To communicate this second commitment to renewal, participants focused on restoring, revitalizing, and supporting the renewal of ethical and transparent practices and communication within the Church and Catholic organizations. An example of this is Leadership Roundtable's online and inperson training on crisis communication. The training includes recommendations and instructions, like designate a response team, "treat key constituents as partners, not audiences," and "keep your logic transparent” (Curley, n.d.).

\section{The Unique Context: Religion and God}

The final research question asks "To what extent does an abstract entity, like God, or unifying issue, like religion, impact the selection of a post-crisis communication strategy?" Data reveal that God and belief in the Catholic faith played a critical role for the majority of participants in two key ways. First, belief in God and the Catholic faith heavily influenced participants' decisions to act after the Boston Globe article was published. Second, participants' faith and relationship with God influenced their decision to practice discourse of renewal, as opposed to criticizing or abandoning the Church, or denying that a crisis exists.

Interview data reveals that God and religion were key factors when participants were deciding how to help, why they wanted to help, and the desired outcome of their support. Specifically, participants' devotion to the Catholic religion and their belief in God's plan for the Catholic Church informed their decisions and actions. Participants described that they didn't want to see the Church "sink," "fail," or "die" as a result of this crisis. They were able to successfully separate the Church and the Church's God-ordained 
mission from the actions of individuals within the Church. To prevent the Church from failing, participants described how they felt it was their duty to God and their religion to act in a way that would help the Catholic Church, Catholic leaders, and Catholic believers recover from the crisis.

According to participants, a crisis within the Catholic Church is unique because it impacts trust in the Church as an organization, and in the Catholic faith. This threat to the Catholic faith, one that participants deeply believe in, served as the primary motivator to act in a way that would not further damage the Church or the reputation of the religion. In other words, participants were worried that criticizing or abandoning the Church would be perceived as criticizing or abandoning the Catholic religion. Therefore, participants focused on "restoration" and "renewal" in order to reestablish faith in the Catholic religion and in the Church, in order to reassure Catholic believers, and in order to gain the trust of Catholic leaders so they could then train them.

While founding members still experienced emotional and spiritual agony as a result of the crisis, data reveals their devotion to their religion and trust in God substantially impacted their post-crisis response, more so than personal or professional desires, values, or ethics. Their belief and faith in the Catholic religion and Church inspired, encouraged, and emboldened their journey toward renewing an organization that deeply hurt them and others.

In conclusion, the results have answered each of the three research questions: (1) Leadership Roundtable practiced discourse of renewal; (2) this stakeholder-formed organization practiced discourse of renewal by communicating a commitment to stakeholders, rebuilding, and renewal; (3) and an abstract entity and unifying issue impacted participants' decisions and actions more than any other factor. The next two sections will provide context for these results and discuss implications for public relations research.

\section{Discussion}

The purpose of this study is to fill gaps in research on crises within religious organizations and post-crisis discourse of renewal. To 
do this, the current study focused on stakeholders' responses to the crisis, as opposed to the offending organizations' efforts or responses. The current study also explored the impact of God and religion on the selection of a crisis response strategy, and explored the ability for a non-offending stakeholder-formed organization to practice discourse of renewal. Scholars have suggested that stakeholder-formed organizations utilize different crisis communication strategies than the offending organization (Boys, 2009). However, the current study is the first known study to examine the ability for stakeholders to practice discourse of renewal.

\section{Five Strategies for Discourse of Renewal}

Interview data reveals Leadership Roundtable practiced and continues to practice the five strategies of discourse of renewal, including a natural and immediate response, forward-thinking discourse that focuses on the future, future possibilities and opportunities as a result of the crisis, communication from a leader, and ethical communication (Ulmer, Seeger, \& Sellnow, 2007; Xu, 2018). Leadership Roundtable practiced the five strategies in a variety of ways, but only key examples for two strategies will be discussed: ethical communication and communication from a leader.

Leadership Roundtable practiced the "ethical communication strategy" by combining Catholic values with ethical communication guidelines from multiple industries. This serves as a stark contrast to previous research, which focused on one organization's values or ethical guidelines from one industry (Seeger \& Ulmer, 2002; Ulmer, Seeger, \& Sellnow, 2007). For instance, Leadership Roundtable combines ethical communication guidelines from Susan King's (current Co-Chair of Leadership Roundtable) career in journalism, with Dubik's career in the U.S. Army, and with Boisi's career in the financial sector. In simpler terms, Leadership Roundtable combined sources and guidelines of ethical communication across industries and then paired those guidelines with Catholic values in order to utilize post-crisis discourse of renewal.

Second, researchers posit that the ethical communication should come from the leader of the offending organization (Seeger \& Ulmer, 2002; Xu, 2018). However, Leadership Roundtable is a stakeholder-formed organization; therefore, their approach 
to this last strategy is unique compared to previous research on discourse of renewal. In sum, ethical communication came from leaders from Leadership Roundtable, who are industry leaders forprofit, non-profit, and government organizations. For instance, Boisi is a leader in the financial sector, Dubik is a retired three-star General, King was the Vice President at Carnegie Corporation, and Robinson was the director of development for Saint Thomas More Catholic Chapel and Center at Yale University. Therefore, the communication came from leaders in various industries who were united through their association with Leadership Roundtable and devotion to the Catholic faith. This distinction is critical to note because it supports the current study's findings that Leadership Roundtable practiced discourse of renewal through each of the five strategies crisis scholars have outlined.

\section{Leadership Roundtable: A Stakeholder-Formed Organization}

A stakeholder-formed organization practicing discourse of renewal is unique and new to this body of literature (Boys, 2009). This finding contributes to our understanding of the practice of public relations, namely that it is not a practice reserved solely for non-profit or for-profit organizations. Indeed, activist groups, individuals, and stakeholder-formed organizations practice public relations and crisis communication (Botan \& Taylor, 2004; Boys, 2009). Additionally, this finding contributes to our understanding of the harm a crisis causes to both organizations and stakeholders. Much of the crisis communication literature details the damage a crisis inflicts on an organization's reputation, trust in the organization, and sales (Anderson \& Guo, 2020; Fuller et al., 2019; Manzie, 2018; Ulmer \& Sellnow, 2000). Understanding the harm to stakeholders is critical in order to understand the threatened expectancies of stakeholders and magnitude of the crisis.

More broadly, determining that stakeholders can practice discourse of renewal highlights the unique concept of a stakeholder-formed organization. Indeed, crises can result in the creation of other organizations. As outlined in the current study and in previous literature, stakeholder-formed organizations are created to help victims of the crisis, to inflict further damage on 
the offending organization, to help the offending organization, and more (Boys, 2009). Investigating the impact of stakeholder-formed organizations on the crisis and on the offending organization's reputation can help scholars advance public relations theory. For instance, data in the current study reveal three distinct groups of stakeholders Leadership Roundtable communicated a commitment to, which is a unique finding for discourse of renewal research.

\section{Limitations}

While this study revealed the experiences of leaders within Leadership Roundtable during and after the Catholic sexual abuse crisis, there are a number of limitations. Primarily, this research focused solely on the experiences and perspectives of leaders within Leadership Roundtable, an organization that has existed for nearly two decades. While the experiences of Catholic leaders who utilize Leadership Roundtable's resource are included in the data analysis and present in the results section, the researcher was not able to elaborate on their individual stories or experiences due to the scope of the research. ${ }^{3}$ Additionally, while the sample size is relatively small for a single-method interview study, this mirrors previous research on discourse of renewal and the requirements for participation in this study were narrow, given the purpose of the research.

Regarding the sampling method for this study, several other stakeholder-formed organizations exist as a result of the sexual abuse crisis. The researcher did not consult or collect data with other organizations so as to narrow the focus of this research. Future studies should include multiple stakeholder-formed organizations to understand how non-offending stakeholder-formed organizations practice post-crisis communication. Lastly, Leadership Roundtable is a unique group of stakeholders; therefore, the applicability of the findings is limited.

3. Of the Catholic leaders interviewed for this project, all revealed that Leadership Roundtable's resources and training have helped them personally, their parishes, and/ or their organizations. 


\section{Conclusion}

The purpose of this research is to assess the potential for a nonoffending stakeholder-formed organization to practice discourse of renewal and explore the extent to which God and religion can impact the decision to act and selection of a post-crisis communication strategy. Through interviews with past and present leaders of Leadership Roundtable, data reveal stakeholders practiced discourse of renewal, formed an organization to support the offending organization, and utilized their personal, professional, and religious values and ethics to practice discourse of renewal. Additionally, leaders' devotion to the Catholic faith and God influenced their post-crisis communication strategy selection.

This research is significant for two reasons. First, the current study expanded the framework for discourse of renewal. The current study determined that stakeholders can practice discourse of renewal, which contributes to the growing body of research on this post-crisis communication strategy. This study also expanded upon certain components within discourse of renewal. For instance, one theme that is consistent within the practice of discourse of renewal is a commitment to rebuild. The current study demonstrated that stakeholders and organizations can communicate a commitment to rebuild trust, policies, and programs, in addition to physical structures, which have been predominantly highlighted in previous research (Seeger \& Ulmer, 2002; Ulmer \& Sellnow, 2002).

Second, the current study considered if and how religion, faith, and God can influence the post-crisis strategy selection and the motivation for stakeholders to engage in post-crisis discourse. This study continues on the work of Tilson and Venkateswaran (2006) to consider the ways religion and belief in God can serve as a unifying factor, influence, or inspiration in crisis communication and relationship-formation.

Importantly, this study has several practical and theoretical implications. Regarding practical implications, the current study demonstrates the importance of relationships and trust between organizations and stakeholders before a crisis occurs. Meaning, without the previously established relationship and trust between 
stakeholders and the Church, stakeholders might not have chosen a post-crisis communication strategy that emphasizes renewal and restoration. This practical implication spans beyond religious organizations and institutions. For instance, research suggests that soccer teams, video games, and political organizations encourage religious-like devotion to the team, politician, and game in similar ways that churches encourage devotion to the faith and God (Spaulding, 2016; Tilson \& Venkateswaran, 2006; Xifra, 2008). Therefore, if a political organization faced a crisis, but also cultivated relationships with their stakeholders, had a history of trust between the organization and stakeholder, and cultivated the religious-like faith in the organization before the crisis occurred, then it is possible that the organization's stakeholders could respond in a similar way as founding members of Leadership Roundtable. The notion that pre-crisis devotion, relationships, and trust between an organization and stakeholders could help the organization recover after a crisis occurs is worth investigating in future research. Overall, more research on the post-crisis communication strategies of non-offending organizations, including stakeholder-formed communities and organizations, would be beneficial to the crisis communication scholarship.

Second, the current study has important theoretical implications. Mainly, the current study demonstrates the importance of considering the context in which organizations exist and the context in which crises occur. Ignoring the religious context and influence of faith and God limits our collective understanding of stakeholder motivations and values within discourse of renewal specifically, but also within crisis communication and public relations research overall.

In conclusion, this study provides insight into the motivations, processes, and history of a stakeholder-formed organization, formed in response to a crisis occurring within a separate institution. In capturing stakeholders' histories, perspectives, and experiences, this study provides insights into discourse of renewal and the influence of religion and God in the practice of public relations and crisis communication. Moving forward, future research should further investigate the influence of faith on the practice of 
public relations, the context in which organizations exist and in which crises occur, as well as the ability for stakeholders to practice post-crisis communication.

\section{Acknowledgment}

The author would like to thank Susan King (Dean of the Hussman School at the University of North Carolina in Chapel Hill) for introducing the author to Leadership Roundtable and for generously funding the research trip to Orlando, Florida, for the Leadership Roundtable Conference.

\section{ORCID}

Jordan Morehouse 으 https://orcid.org/oooo-0002-8584-2957

\section{References}

Agné, H., Dellmuth, L. M., \& Tallberg, J. (2015). Does stakeholder involvement foster democratic legitimacy in international organizations? An empirical assessment of a normative theory. The Review of International Organizations, 10(4), 465-488. https://doi.org/10.1007/s11558-014-9212-6

Anderson, L. B., \& Guo, J. (2020). Paradoxical timelines in Wells Fargo's crisis discourse: Expanding the discourse of renewal theory. International Journal of Business Communication, 57 (2), 212-226. https://doi.org/10.1177/2329488419882761

Barth, T. (2010). Crisis management in the Catholic Church: Lessons for public administrators. Public administration review, 7o(5), 780-791. https://doi.org/10.1111/j.15406210.2010.02205.X

Botan, C. H., \& Taylor, M. (2004). Public relations: State of the field. Journal of Communication, 54(4), 645-661. https://doi. org/10.1016/j.pubrev.2012.09.002

Boys, S. (2009). Inter-organizational crisis communication: Exploring source and stakeholder communication in the Roman Catholic clergy sex abuse case. Rhetorical and Critical Approaches to Public Relations, 290-309. 
Catholic Church Child Sexual Abuse Scandal (2019, February 26). Catholic Church child sexual abuse scandal. Archived at https:// web.archive.org/web/20200208094242/https://www.bbc.com/ news/world-44209971

Coombs, W. T. (2007). Protecting organization reputations during a crisis: The development and application of situational crisis communication theory. Corporate Reputation Review, 1o(3), 163-176. https://doi.org/10.1057/palgrave.crr.1550049

Coombs, W. T. (2009). Conceptualizing crisis communication. Handbook of risk and crisis communication, 99-118.

Curley (n.d.). Communication in a Time of Crisis. Retrieved from http://theleadershiproundtable.org/churchepedia/communi cations/parish-communication.html

Dokecki, P. R. (2004). The clergy sexual abuse crisis: Reform and renewal in the Catholic community. Georgetown University Press.

Donnelly, S., \& Inglis, T. (2010). The media and the Catholic Church in Ireland: Reporting clerical child sex abuse. Journal of Contemporary Religion, 25(1), 1-19. https://doi. org/10.1080/13537900903416788

Fuller, R. P., Ulmer, R. R., McNatt, A., \& Ruiz, J. B. (2019). Extending discourse of renewal to preparedness: Construct and scale development of readiness for renewal. Management Communication Quarterly, 33(2), 272-301. https:/doi.org/ 10.1177/0893318919834333

Glaser, B. G., \& Strauss, A. L. (1967). The discovery of grounded theory: Strategies for qualitative research. Aldire.

Green, E. (2019, February 14). Why does the Catholic Church keep failing on sexual abuse? Archived at https://web.archive.org/ web/20190214145319/https://www.theatlantic.com/politics/ archive/2019/02/sean-omalley-pope-francis-catholic-churchsex-abuse/ $582658 /$

Howard-Payne, L. (2016). Glaser or Strauss? Considerations for selecting a grounded theory study. South African Journal of Psychology, 46(1), 50-62. https://doi.org/10.1177/0081246315 593071 
Hurst, D. (1995). Crisis and renewal: Meeting the challenge of organisational change. Harvard Business School Press.

Keenan, M. (2013). Child sexual abuse and the Catholic Church: Gender, power, and organizational culture. Oxford University Press.

Kirchgaessner, S. (2015, November 3). Vatican hit by new claims of financial mismanagement and lavish spending. Archived at https://web.archive.org/web/20151104200751/https://www. theguardian.com/world/2015/nov/03/vatileaks-scandaldeepens-resistance-to-papal-reform

Leadershiproundtable.org. (n.d.) Standards for Excellence. Archived at https://web.archive.org/web/20180831160146/ http://theleadershiproundtable.org/sfx/about-the-standards/ default.asp

Maier, C. T. (2005). Weathering the storm: Hauser's Vernacular Voices, public relations and the Roman Catholic Church's sexual abuse scandal. Public Relations Review, 31(2), 219-227. https://doi.org/10.1016/j.pubrev.2005.02.017

Manzie, V. D. (2018). Applying the rhetoric of renewal model in a contemporary African context: Lessons learned from the royal Dutch shell oil crisis in Nigeria. Journal of International Crisis and Risk Communication Research, 1(2), 201-224. https://doi. org/10.30658/jicrcr.1.2.2

Merriam, S. B. (2009). Qualitative research: A guide to design and implementation (3rd ed.). John Wiley and Sons.

Robinson, W. V. (2002, January 31). Scores of priests involved in sex abuse cases. Archived at https://web.archive.org/ web/20200310043537/https://www.bostonglobe.com/news/ special-reports/2002/01/31/scores-priests-involved-sexabuse-cases/kmRm7JtqBdEZ8UFoucR16L/story.html

Seeger, M. W., \& Griffin Padgett, D. R. (2010). From image restoration to renewal: Approaches to understanding postcrisis communication. The Review of Communication, 1o(2), 127141. https://doi.org/10.1080/15358590903545263

Seeger, M. W., \& Ulmer, R. (2002). A post-crisis discourse of renewal: The cases of Malden Mills and Cole Hardwoods. Journal of Applied Communication Research, 30(2), 126-142. https://doi.org/10.1080/00909880216578 
Spaulding, C. (2016). Applying the devotional-promotional model to the video game "Faithful." Public Relations Review, 42(2), 359-365. https://doi.org/10.1016/j.pubrev.2016.01.004

Spaulding, C. (2018). Evangelical Christian crisis responses to same-sex sex scandals. Journal of Media and Religion, 17(1), 28-40. https://doi.org/10.1080/15348423.2018.1463717

Strauss, A., \& Corbin, J. (1998). Basics of qualitative research techniques. Sage Publications.

Thompson, B., Jerome, A. M., Payne, H. J., Mazer, J. P., Kirby, E. G., \& Pfohl, W. (2017). Analyzing postcrisis challenges and strategies associated with school shootings: An application of discourse of renewal theory. Communication Studies, 68(5), 533-551. https://doi.org/10.1080/10510974.2017.1373370

Tilson, D. J., \& Venkateswaran, A. (2006). Toward a covenantal model of public relations: Hindu faith communities and devotional-promotional communication. Journal of Media and Religion, 5(2), 111-133. https://doi.org/10.1207/ s15328415jmro502_3

Ulmer, R. R., Seeger, M. W., \& Sellnow, T. L. (2007). Post-crisis communication and renewal: Expanding the parameters of post-crisis discourse. Public Relations Review, 33(2), 130-134. https://doi.org/10.1016/j.pubrev.2006.11.015

Ulmer, R. R., \& Sellnow, T. L. (2000). Consistent questions of ambiguity in organizational crisis communication: Jack in the Box as a case study. Journal of Business Ethics, 25(2), 143-155. https://doi.org/10.1023/A:1006183805499

Ulmer, R. R., \& Sellnow, T. L. (2002). Crisis management and the discourse of renewal: Understanding the potential for positive outcomes of crisis. Public Relations Review, 28(4), 361-365. https://doi.org/10.1016/s0363-8111(02)00165-o

Wastell, D. G., McMaster, T., \& Kawalek, P. (2007). The rise of the phoenix: Methodological innovation as a discourse of renewal. Journal of Information Technology, 22(1), 59-68. https://doi. org/10.1057/palgrave.jit.2000086

Xifra, J. (2008). Soccer, civil religion, and public relations: Devotional-promotional communication and Barcelona Football Club. Public Relations Review, 34(2), 192-198. https:// doi.org/10.1016/j.pubrev.2008.03.005 
Xu, S. (2018). Discourse of renewal: Developing multiple-item measurement and analyzing effects on relationships. Public Relations Review, 44(1), 108-119. https://doi.org/10.1016/j. pubrev.2017.09.005

Yang, A., \& Taylor, M. (2014). Looking over, looking out, and moving forward: Positioning public relations in theorizing organizational network ecologies. Communication Theory, 25(1), 91-115. https://doi.org/10.1111/comt.12049 